\title{
Tourism as a Factor of City Development in the Post- Industrial Economy
}

\author{
Svetlana R. Khusnutdinova \\ Department of theory and methodology of geographical and \\ environmental education \\ Kazan Federal University \\ Kazan, Russia \\ hsvr@yandex.ru
}

\author{
Daniiar F. Sadretdinov \\ Department of Socio-Economic and Humanitarian \\ Disciplines \\ Volga Region State Academy of Physical Culture, Sport and \\ Tourism \\ Kazan, Russia \\ sadretdinov.daniiar@yandex.ru
}

\author{
Rustem R. Khusnutdinov \\ Physics department \\ Kazan State Power Engineering \\ Kazan, Russia \\ khrr@yandex.ru
}

\begin{abstract}
The article is devoted to the study of city tourism. City tourism is now practiced across the whole world; however, it is undervalued in city management as well as in academic research. City tourism is not a new form of tourism as such; as a matter of fact, people have always visited cities with a variety of purposes (business, recreation, to visit friends or relatives etc.). The change in the approach has taken place in post-industrial economy, when its importance in developing the city economy in terms of social, cultural, employment and revenue improvement has become apparent. The case-study method is used in the research. The city of Kazan is the capital of Republic of Tatarstan. The Republic of Tatarstan is one of the most socialeconomic developed region of Russian Federation with population about 3,8 million. 'Developed' and 'basic' factors of tourism development of the City of Kazan were analyzed, as well as dynamic of tourist flows (with accomodation) and number of hotels of Republic of Tatarstan. The most effective way to develop city tourism is combining 'developed' and 'basic' factors of tourism.
\end{abstract}

Keywords: city, tourism, urban tourism

\section{INTRODUCTION}

One of feature of contemporary global economy is the increase of mobility - mobility of people, as well as business, investments and ideas. One of the most important aspect of people mobility is tourism, both as domestic tourism and international. 1.1 billion tourists traveled the world and tourism generated US\$1.1 trillion in 2018 [1]. According to forecast of World Tourism Organization UNWTO, international tourist arrivals will reach 1.8 billion by 2030 [2].
The growth of tourist flow means opportunity for residents to expand business, to improve income and create new activities and jobs. There are two key aspects: large cities and agglomerations become most important destination of tourist flows and tourism becomes important component of city economy [3].

In post-industrial era the large cities needs to develop tourism industry in the cities. On the one hand, cities have a variety of features to attract tourists - heritage for culture tourism, infrastructure, congress and exhibition venue for business trips, festivals, sport-events, shops, entertainment for leisure tourism etc [4]. City tourism takes place every season during the whole year and does not depend on climate and weather as sea resorts or mountain environments. Cities have diverse places, event and opportunity to spend time in any weather and the whole year may be the tourist season.

On the other hand, cities have to deal with the problem of growth of population and unemployment and have to provide residents (and migrants) a new job. Tourism has the ability to bring income and investments into the city and can be described as an 'export' branch [2].

\section{METHODS}

The study has taken into account the city of Kazan with population over 1,2 million people. The city of Kazan is one of the 14 cities of Russian Federation with population from 1,0 to 2,0 million, all of this cities are regional capitals and they had industrial specialization during 20 century. Now they are experiencing transformations of the post-industrial economy 
and are looking for new development opportunities. The casestudy method was used in the research. The statistic base for the study was data of the State committee on tourism of the Republic of Tatarstan.

\section{RESULTS AND DISCUSSION}

By Law the idea "of great potential importance" of city tourism had been accepted by US major cities, and then in 1980-90s "diffused to Britain and the rest of Europe with much copying of attractions, buildings and even place-names" [5]. And now we can see increasing interest to tourism theme and city tourism in east Europe and publication on this topic or part of it [6-9].

City tourism as "young" phenomenon should be considered as one of the modern city development processes, which has connection with such essential processes as gentrification, for example.

City tourism or urban tourism is a part of urban development. When we talk about possibility of development tourism in the city, first of all, we remember such remarkable tourist center as Paris, New-York, London, Rome. Then we try to compare any city with them as the icon or best model of city tourism, but not so many cities have such heritage or contemporary art as Paris or Rome and such experience in organizing tourism street navigation or coherent transport infrastructure as London or Vienna. However one of the main goal of city tourist is visit of new place with own face and identity. Therefore, other cities have a chance to create conditions for the development of the tourist industry and increase the flow of tourist.

In our opinion, urban tourism is travel with intents to communicate with another people, another culture, another lifestyle, another event etc. related to the urban territory and urban environment.

The city tourism attracts creative people and provides new activities, besides involving citizens and local residents who become active participants in the city economy. Furthermore, it helps preserve historical and culture heritage and provides sustainable development of the City.

In spite of absolute clarity of meaning of term "city tourism" or "urban tourism" in "normal" life there are not common scientific or statistic term of this definition.

Theme of urban or city tourism began to be discussed in the scientific literature relatively recent $-30-40$ years ago. At 1960-70s by opinion of Deborah Edwards, Tony Griffin and Bruce Hayllar city tourism research was "fragmented and not recognized as a distinct field". At 1980s there was increase of interest to urban tourism as "distinct phenomenon and area of research" [10].

Pearce noted in his work "An Integrative Framework for Urban Tourism Research" that theme of urban tourism became "significant and distinctive field of study during the 90s" [4].

As it was said above, now interest in research of tourism in a whole and the city tourism particularly is expanding to Central and Eastern Europe. There are several example of city tourism development in the east Europe and post-socialist (post-communist) countries such as Lodz (Poland), Bratislava (Slovakia), Kaliningrad (Russia), Lviv (Ukraine), Minsk (Belarus) in the book "Tourism and transformation of large cities in the post-communist countries of Central and Eastern Europe [7].

Publication on theme of city tourism may be divide in several main types. First of them include case-study of different cities and the questions of tourism development [1116]. Second type of articles may be named 'organized'. These articles are devoted to research of management and organizing of city tourism, city branding and image and types of tourism (sport and culture event, etc.) [17-21]. In the first case, the experience of both cities with historical background and traditions in the organization of tourism, as well as cases of "beginners" of the tourism sector are revealed.

In the second case, considerable attention is paid to the strategy planning of territorial development with a focus on tourism, the brand and the image of the city, and the possibilities of developing modern tourism related to attending events (sports, cultural, etc.)

In both types of works the complexity of urban tourism is noted, as well as the difficulty in identifying its role in the economy.

There are several main segments of City Tourism:

- museum, historical and culture heritage;

- business;

- entertainment (aqua-park, adventure-park, concert, shows);

- events (culture, sport, science);

- shopping;

- visit friends and family

and all of the facilities and the infrastructure of this segments can be used by residents. There is also a reverse trend. Infrastructure, facilities, parks, events, museums, etc. are created residents for themselves be able to use by tourists and attract them $[12,22]$.

A variety of factors influences on the city tourism development. That means there is need of systematization of the factors. One of the systematization approach is based on dividing all the destination factors attracted tourist into two group - "developed" and "based".

"Developed factors" - business venues and congress halls, shops and malls, aqua-parks and adventure-parks, sport and culture events, contemporary arts galleries etc. Creation of them demands effort, investments, skills, knowledge from public and private sector of contemporary city community administration, local business, stakeholders, people who are living in the city.

"Basic factors" - heritage, nature, warm sea, mild climate etc. and old brand of tourism centre. We can name them "Gift", because they didn't demand any effort of 


\section{B. Business ("developed" factors of tourism)}

contemporary generation of citizens. The most effective path of strategy city tourism development is to combine both of two groups of factors. Historical and culture heritage makes unique destination and "developed" factors such as sport world event or creative, culture, music festival could make the city more attractive for tourism for several days. Event tourism is one of the most popular segments of city tourism and includes next types: cultural (festivals, carnivals, etc.), political and state (summits conferences, meetings, etc.), arts and entertainment (concert, exhibitions, shows, award ceremonies, etc.), business and trade (meeting, conventions, consumer and trade shows, fairs, markets), educational and scientific (conference, seminars, etc.), sport and private events.

\section{CASE STUdy OF THE City OF KAZAN}

Tourism becomes important part of the socio-economic development in different regions of Russian Federation. On the one hand, Russia one of the leader of the growth of international tourism spending.

On the other hand, country has various "basic" factors of tourism development - largest territory and the various natural and climatic conditions, rich heritage and large cities. Traditional tourism cities of Russia - Moscow and SaintPetersburg which has both "basic" tourism factors - heritage and old brand of tourism center, and "developed" - culture event and venue of business tourism and meeting industry.

The city of Kazan is the capital of Republic of Tatarstan. The Republic of Tatarstan is one of the most social-economic developed region of Russian Federation with population about 3,8 million. The city of Kazan is located about $800 \mathrm{~km}$ to east from Moscow. The population is about 1,2 million citizen. Kazan has thousand-year-old history. There is one of the three oldest university of Russia - Kazan Federal University. As another large city of Russia Kazan had industry specialization, but as many contemporary cities was looking for new opportunities for development - for investment, for creation new jobs, new income.

Since beginning of 2000s the Republic of Tatarstan and the city of Kazan actively develop tourism industry. There are programs of tourism developing "The Republic target program "Developing of tourism sphere of the Republic of Tatarstan for 2009-2011 years", "Developing of tourism sphere of the Republic of Tatarstan for 2013-2016 years", "Developing of tourism and hospitality sphere of the Republic of Tatarstan for 2014-2020 years. The City of Kazan has brand "Third capital of Russia" and many attractive factors for tourism. The main segments of city tourism of Kazan are heritage, business, entertainment and event.

\section{A. Heritage of Kazan ("basic" factors of tourism)}

The main heritage destination of city and republic is the Kazan Kremlin Architectural Ensemble. Kazan Kremlin is UNESCO world heritage site. The Suyumbika Tower, the Blagoveshchensky Cathedral, the Governor's Palace, the Kul Sharif Mosque are famous ensemble elements of the Kremlin.
City has venues for conducting international meeting. One of the main is the Korston Hotel \& Mall Kazan, which was be opened in 2006 year. For example, Korston Hotel \& Mall Kazan was the venue of the Congress of the Organization of World Heritage cities - 2007. At 2019 the City of Kazan was host of the 45th World Skills Competition. Representatives from 63 countries attended.

\section{Entertainment ("developed" factors of tourism)}

The City of Kazan offers various types of entertainment such as cinema, concert, theater, clubs. The main tourism place of entertainment is aquapark "Riviera". Kazan "Riviera" aquapark was opened in 2006. This entertainment venue is one of the largest in the world. The entertainment infrastructure of the city is diverse and can be used in both summer and winter seasons.

\section{Event ("developed" factors of tourism)}

The City of Kazan conducted Summer Universiade (World Student Games) at 2013 year, the World Aquatics Championships at 2015 year, the FIFA Confederations Cup at 2017 year, the FIFA World Cup at 2018.

Since 2008 when Kazan was announced as the host city for the 2013 Summer Universiade the city and republic were preparing to world sport-event and interest to the city as tourism destination with different opportunities increased. The flow of tourism as a number of hotels increased every year after this sport-event (Fig.1).

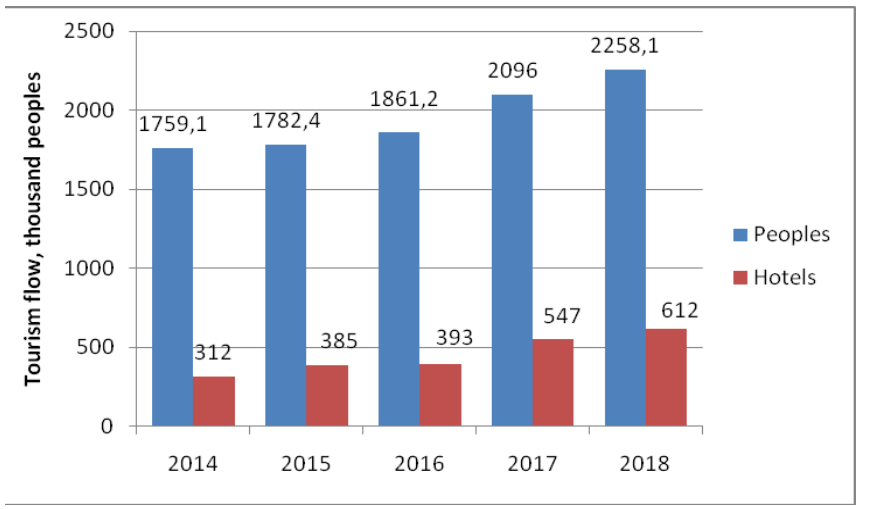

Fig. 1. Dynamic of Tourist Flow (with accomodation) and number of hotels of Republic of Tatarstan. Source: Elaborated by author based on the data from the State committee on tourism of the Republic of Tatarstan (https://ias.tatar.ru/ipad/open_rt_view.php?id=29399 DoA: 29th November 2019)

At the period of Universiade-2013 there were about 12 thousand participants from 160 countries and more than 150 000 tourists from Russia and other country. As the result of sport event tourism for city development can be identify 2 part - 'material' and 'immaterial' (intangible) results.

As stated earlier, determining the exact economic role of events is a difficult task. The costs of the sport-event involve direct expenditures on sports building, indirect expenditures on infrastructure from transport to hotels and cafes (HoReCa), the operating costs of the sport games themselves and the 
groups: "basic" and "developed". The most effective way to develop city tourism is combining both of them. One of the most important type of city tourism - event tourism - is based on "developed" factors. Benefits from hosting world event can have long-term effects and may be divided into "material" and "immaterial". In the case of Kazan, city tourism development is based on both groups of tourism factors - heritage ("basic") and entertainment, business and events ("developed"). In particular, a world sport event such as Universiade-2013, which took place in July 2013 in the city of Kazan, has brought about long-term effects for the city development that are both of a material nature (investments, transport infrastructures, new buildings, preserving heritage, creation of new green spaces) and of an immaterial nature (enhanced visibility of the city in terms of brand, patriotism and pride for city, healthy lifestyle, valuable experience in hosting world events.

\section{REFERENCES} new road junction, finishing of building of first line of metro. One of the most important object of transport infrastructure international airport "Kazan" was renovated and now able to increase of value of passengers and extend of the geography of flights.

As 'immaterial' or intangible results should be considered - brand of Tourism City, patriotism and pride for city, healthy lifestyle, culture universiade, experience in organizing and conducting world event.

\section{CONCLUSION}

Tourism industry has become one of the major sources of income, employment, growth and revenue for many countries and cities. Tourism is effective as a means of taking part in the global economy and can be a resource for sustainable development of the cities. Large cities are in the process of turning into the important tourism destination of the world.

Tourism itself is playing a key role in social-economic development of the city in the post-industrial era. The development of city tourism can be defined as a contemporary process of urban evolution. Probably different cities of the world may undergo the same trajectory of urban tourism development. In our opinion, exploring this issue may provide an understanding of the principles and patterns of city development and tourism industry development.

City tourism has a multipurpose character and is closely connected with "every day" life of citizens. Residents are using the same infrastructure, entertainment and event venues for recreation as tourists. It is very difficult to distinguish the accesses due to tourists visits from those due to residents. Moreover, there is not a common scientific or statistic definition of city or urban tourism.

There are several main segments of city tourism, which also can be enjoyed by residents: heritage (museums, architectural monuments); business; entertainment; events; shopping; visit friends and family. All of them contribute to developing the city tourism industry, which is influenced by different factors. These factors can be divided in two main
[1] "UNWTO World Tourism Barometer", 2019 [Electronic resource]. Available at: https://www.unwto.org/market-intelligence (Accessed: 20 January 2020).

[2] "UNWTO Climate Change", Transport-related CO2 Emissions of the Tourism Sector - Modelling Results, 2019 [Electronic resource]. Available at: https://unwto.org/sustainable-development/climatechange (Accessed: 20 January 2020).

[3] C. M. Law, "Urban Tourism and its Contribution to Economic Regeneration", In: Urban Studies, 1992, vol. 29, no. 3/4, pp. 599-618.

[4] D. G. Pearce, "An Integrative Framework for Urban Tourism Research", In: Annals of Tourism Research, 2001, vol. 28, issue 4, pp. 926-946. DOI: 10.1016/S0160-7383(00)00082-7.

[5] C. M. Law, "Urban Tourism: The Visitor Economy and the Growth of Large Cities", 2-nd Edition, Great Britain Cromwell Press, Trowbridge, 2002 .

[6] W. Cudny, "Film Festivals in Lodz as a main component of urban cultural tourism", In: Bulletin of Geography, 2011, no. 15, pp. 131141. DOI: 10.2478/v10089-011-0009-6.

[7] W. Cudny, T. Michalski, and R. Rouba, "Tourism and the Transformation of Large Cities in the Post-Communist Countries of Central and Eastern Europe", Łódź: Szlakami Nauki, 2012.

[8] A. Grenčíkova, S. Vojtovic, and M. Gullerova, "Staff Qualification and the Quality of Tourism-Related Services in the Nitra Region", In: Bulletin of Geography, 2013, no. 21, pp. 41-48. DOI: $10.2478 / \mathrm{bog}-$ 2013-0019.

[9] B. Holowiecka and E. Grzelak-Kostulska, "Globalisation as a major factor modifying the patterns of tourism activity", In: Bulletin of Geography, 2013, no. 21, pp. 49-60. DOI: 10.2478/bog-2013-0020.

[10] D. Edwards, T. Griffin, and B. Hayllar, "Urban Tourism Research Developing an Agenda", In: Annals of Tourism Research, 2008, vol. 35, issue 4, pp. 1032-1052. DOI: 10.1016/j.annals.2008.09.002

[11] R. Campos and A. Sequeira, "Urban Art touristification: The case of Lisbon", Tourist Studies, 2019, UNSP 1468797619873108. DOI: 10.1177/1468797619873108.

[12] S. Paul, "Analysing tourism attractiveness using probabilistic travel model: A study of Gangtok and its surroundings", European Journal of Geography, 2013, no. 4 (2), pp. 46-54.

[13] K. Ota, "Changing waterbus routes and increasingly diverse boat designs in the Tokyo Rinkai (waterfront) area", European Association of Geography, 2014, no. 5 (4), pp. 47-55.

[14] L. A. Pereira, P. F. Limberger, L. C. S.Flores, and M. L. Pereira, "An Empirical investigation of destination branding: The case of the city of Rio de Janeiro", Brazil, Sustainability (Switzerland), 2019, vol. 11, no. 90. 
[19] M. Schnitzer and M. Barth, "Does sport event satisfaction remain stable over time?", International Journal of Tourism Research, 2019, vol. 21, issue 6, pp. 785-789. vol. 10, issue 6, pp. 705-711.

[16] A. Santos and M.Cincera, "Tourism demand, low cost carriers and European institutions: The case of Brusselsv (Review)", Journal of Transport Geography, 2018, vol. 73, pp. 163-171.

[17] P. Rizzi and I. Dioli, "From Strategic Planning to City Branding: Some Empirical Evidence in Italy", In: Pasos: Journal of Tourism and Cultural Heritage, 2010, vol. 8, no. 3, pp. 39-49 [Electronic resource]. Available http://www.pasosonline.org/Publicados/8310special/PS0310_05.pdf.

[18] S. Budak and S. E. Kavanoz,2019, "The Process of Promoting Small Cities through Local and Authentic Values: City Tourism in the Time of Globalisation", Istanbul University Jornal of faculty of political sciences, 2019, vol. 28, issue 2, pp. 117-140. DOI: 10.26650/siyasal.2019.28.2.0043.

[20] G. Richards, "Measuring the dimensions of event experiences: applying the Event Experience Scale to cultural events", Jornal of policy research in tourism leisure and events, 2019. DOI: 10.1080/19407963.2019.1701800.

[21] J. Zhang, K. K. Byon, A. S. Williams, and H.Huang, "Effects of the event and its destination image on sport tourists' attachment and loyalty to a destination: the cases of the Chinese and U.S. Formula One Grand Prix" Asia Pacific Journal of Tourism Research, 2019, vol. 24, issue 12. pp. 1169-1185.

[22] G. Ashworth, "Do we Understand Urban Tourism? ", In: J Tourism Hospit 1: e117, 2012. DOI: 10.4172/2167-0269.1000e117. 